\title{
Damage Done by Weed Sprays
}

by Mrs. E. K. Hubbard, Grenfell

We have been hearing a lot lately about the widespread use and danger of insecticides, but nct as much is said about the harm done by the use of sprays to kill weeds in the crop and to keep down shrubiby growth along roads and power and telephone lines. One cannot blame the farmer for using sprays to combat the weeds, or the municipality for using an effective means of keeping their roadsides clear, or the power or telephone companies for using this means of keeping down tree growth that will interfere with the operation of their lines. However, there is somebody who should be considered, who at the present time is being ignored and that is the farmer who is trying to beautify his farm grounds with shelterbelts, ornamental shrubs, perennial and annual flowers, and who may or may not have an orchard of small fruits. Here, with spray blowing in from many sources, and with the drift of fumes in still air, a great deal of damage may be done without the owner being definitely sure of the source of the harm.

Let me cite our own experience as an example. We live about onequarter mile west of a highway which has telephone poles on one side and long distance power lines on the other. Last summer the Power Corporation (by local or provincial behest I know not) sprayed all the bush along the highway under their line. The municipality sprayed the roadsides three-quarter mile to the south and three-quarter mile to the west of our farm buildings. Then one calm evening the odour of spray came drifting in from the northwest, presumably from a neighbour's spraying during the day.

I believe the instructions that come with spray recommend that it is not to be used on windy days. This is one recommendation that is not strictly followed. I do not know whether the farmer who sprays in a 10 to $15 \mathrm{~m} . \mathrm{p} . \mathrm{h}$. wind gets effective results from his spraying but I do know that his spray will travel a mile to a mile and a half and do damage at the end of that journey. I also know that even on what seems to be a perfectly still day spray fumes will drift long distances.

With regard to the damage that has been done at the farm here frcm spray, that to the Manitoba maples in the shelterbelt is the most noticeable. These trees are now eleven years old but they have been dwarfed by yearly damage from spray. The first year I saw the elongated yellowish tips on the branches I thought they were diseased or had received insect damage, but was informed by the Fcrest Nursery Station at Indian Head that this was spray damage. We had done no spraying ourselves that year. Every year these trees show the same damage. It looks as if Manitoba maples are doomed.

Many types of plants show damage from weed killers without being killed, or immediately killed. The growing tips of their branches or stems are elongated unnaturally, frequently are twisted, sometimes the foliage is lighter in colour than on the rest of the plant, frequently the plant's flowering is reduced or stopped altogether and the plant or tree becomes stunted. Manitoba maple, ginnala maple, tree lilacs, honeysuckle and spireas show the branch damage, though only the tree lilacs have refused to flower. The flower stems of pecnies grow very long but flowering does not seem to be restricted. Daylilies, on the other hand, hardly flower at all, and the few flowers they do have are on very long flower stalks.

Two Heyer apples in the crchard this summer showed this extreme tip growth but had an enormous crop of apples; it will be interesting to see if they survive. I am now wondering if well-established Rescue apples and some plum trees which suddenly died without any visible cause may not have been harmed by spray.

One perennial that is evidently very susceptible is the double Golden Glow. It produced elongated twisted stems which turned black and died the year of damage, and the whole plant was dead the next spring.

These are just some of the effects of spraying that I have noticed myself. With spraying as widespread as 
it now is this recital of spray damage must be multiplied many times across the country. I believe the time has come when we must decide if we are to allow all plants susceptible to spray to vanish entirely. Are we to sacrifice all the beauty of roadside growth to good "road" housekeeping?

I would like to make the following suggestions:

1. Before the ultimate results of widespread spraying have been reached a comprehensive study of this problem should be made by governments, agricultural organizations, natural history organizations and scientists to determine what growth will be completely eliminated, and whether efforts should be made to protect certain trees, shrubs, flowers, etc.

2. In Montana there is a law applying to aeroplane spraying that requires the farmer and operator to fill out a report concerning conditions of spraying. Any complaints arising from the spraying should be made within 30 days. If such reports had to be made both the spray operator and those ordering the spraying would tend to use more care in their operations. Such reports wculd form a body of information to help study the whole spray situation.
3. Information should be made available to everyone through pamphlets accompanying weed killers, thrcugh farm and garden publications, University and Experimental Farm publications ,etc., of:

(a) The distances which spray will travel under different wind speeds, under various pressures, and from different heights of spraying.

(b) The various types of trees, shrubs, flowers, orchard and small fruits that are susceptible to spray. This information would alert the spray cperatcr to the damage he may be causing to native growth, and to nearby shelterbelts, orchards, borders and gardens.

4. Lists of plants particularly susceptible to weed killers should be available for the protection of the buying public, and seed companies and nurseries shculd list this information in their catalogues.

5. Study should continue to find pcssible antidotes or action to counteract the effects of spray on susceptible plants when we know they have been expcsed to spray.

Note: This timely article by one of our SNHS members is reprinted from The Gardener's Bulletin, Vol. 3, No. 2, April, 1964. Copies of it have also gone to the Saskatchewan Departments of Agriculture, Highways, and Municipal Affairs.

\section{Plant Distributions on Kernen's Prairie, Saskatoon}

by Graham B. K. Baines, University of Saskatchewan, Saskatoon

Kernen's Prairie consists of 320 acres of grassland which, despite the uitability of this land for cropping, have escaped cultivation and have hot experienced grazing since the 1930's. This may be the last sizeable emnant of the original grassland regetation of the glacial lake soils of he area. It is situated approximately ive miles east of Saskatoon.

This prairie, particularly when iewed from the air, appears as a mosaic of grassland interspersed with atches of shrub and Aspen Poplar Populus tremuloides). Such heteroseneity of vegetation reflects the ariations in soil and drainage conlitions which occur in the area. Durng the summer of 1963 the author, or his master's research, undertook a study of the distribution of plant species within the area in relation to these soil and drainage variations. This paper is a generalized account of the flora, with incidental observations of the fauna; further details of the vegetaticn can be obtained by referring to the University of Saskatchewan, M. Sc. thesis, Plant distribution on a Saskatchewan prairie in relation to edaphic and physiographic factors.

Slopes in the area are very slight and never exceed about two degrees yet this suffices to produce a pronounced change in habitat. The amount of soil moisture increases, as does the soil crganic matter, depth of soil and acidity as one proceeds downslope from the relatively dry 